\title{
PENGARUH PERUBAHAN MANAJEMEN TERHADAP BUDAYA ORGANISASI DALAM RANGKA MENINGKATKAN KINERJA MANAJER DI PT. ALFA RETAILINDO Tbk.
}

\author{
Hans Harischandra \\ Email: hans_hchandra@bundamulia.ac.id
}

\section{Penulis}

Hans Harischandra adalah staf pengajar tetap di Jurusan Manajemen, Universitas Bunda Mulia, Jakarta dan menjadi koordinator dalam mata kuliah bidang bisnis retail. Bidang peminatan: manajemen bisnis retail.

\section{Abstrak}

Pulihnya kondisi ekonomi makro Indonesia pasca krisis ekonomi tahun 1997 berdampak positif terhadap perkembangan bisnis ritel di dalam negeri, khususnya ritel modern. Kehadiran sejumlah peritel global kelas dunia seperti Makro, Lion Super Indo, Sogo, dan lainnya, semakin memperketat persaingan bisnis ritel modern. Persaingan bisnis ritel modern ini diramaikan dengan adanya perang harga (price war) yang dapat mengarah kepada perang toko (store war). Memang banyaknya gerai tercipta banyak sekali peluang pekerjaan untuk pengembangan karir pegawai. Namun juga mengakibatkan labor turn-over SDM yang tinggi pada perusahaan ritel, sehingga di sisi lain para peritel lokal yang memiliki sumber daya manusia potensial semakin merasa terancam dengan kondisi persaingan yang kurang sehat seperti ini.

\section{Kata Kunci}

Perubahan manajemen, budaya organisasi, kinerja organisasi, kinerja manajer.

\section{PENDAHULUAN}

Dengan adanya perubahan lingkungan industri ritel modern, telah membawa pengaruh yang signifikan juga terhadap kondisi kinerja PT Alfa Retailindo Tbk., (atau lebih dikenal dengan sebutan 'Alfa'), sebuah perusahaan ritel lokal nasional 
yang berdiri sejak tahun 1989 di Jakarta. Oleh karena perubahan lingkungan industri ritel modern yang semakin kompetitif akhir-akhir ini, maka Alfa harus mempertimbangkan berbagai upaya strategi bisnis yang lebih adaptif agar mampu bersaing dan mendapatkan pangsa pasar yang proporsional. Dalam hal ini, terutama dalam menghadapi persaingan bisnis ritel modern saat ini, Alfa sedang melakukan perubahan terencana dalam upaya meningkatkan kinerja perusahaan. Persaingan bisnis ritel modern dengan sesama peritel yang sudah hadir, ditambah dengan hadirnya beberapa peritel lokal maupun global di sekitar gerai-gerai Alfa, semakin menekan tingkat pertumbuhan penjualan di banyak gerai Alfa dan berdampak secara signifikan pada perolehan laba usaha secara menyeluruh. Inilah yang menjadi alasan kuat mengapa Alfa melakukan perubahan terencana.

Sejak tahun 1989 berdirinya Alfa, Djoko Susanto sebagai pendiri sekaligus Presiden Direktur (CEO) PT Alfa Retailindo Tbk. memandang bahwa kehadiran peritel asing yang meramaikan persaingan bisnis ritel modern di Indonesia merupakan tantangan bersama antara dirinya beserta seluruh karyawan. Dengan gaya kepemimpinan partisipatifnya yang efektif selama ini, Djoko Susanto mengutamakan kepercayaan terhadap integritas dan kemampuan profesional lokal, semangat kebersamaan dan kekeluargaan dalam team work yang solid dan bekerja keras untuk menuju visi-nya, yaitu Alfa menjadi peritel terkemuka dan sekaligus berusaha membuat Alfa tetap survive.

Seiring dengan perubahan lingkungan industri ritel modern, khususnya persaingan bisnis ritel modern yang makin ketat dan menekan angka penjualan serta perolehan laba bersih Alfa dilakukanlah pergantian kepemimpinan (regenerasi) di Alfa. Tujuannya adalah untuk merumuskan kembali konsep dan strategi bisnis Alfa yang lebih efektif dalam menghadapi persaingan bisnis ritel modern dan tetap menjadikan Alfa peritel terkemuka di Indonesia. Secara resmi, pada tanggal 27 Juni 2004 melalui Rapat Umum Pemegang Saham Luar Biasa PT Alfa Retailindo Tbk. Presiden Direktur (CEO) Alfa digantikan oleh Rullyanto
Lukman.

Kehadiran Rullyanto Lukman sebagai pemimpin Alfa yang baru membawa angin perubahan yang sangat besar dalam kehidupan organisasi perusahaan Alfa. Sejak menjabat sebagai Presiden Direktur PT Alfa Retailindo Tbk. Rullyanto Lukman melakukan perubahan manajemen, antara lain :

1. Perubahan konsep dan strategi bisnis diikuti dengan perubahan strategi merchandising, pricing policy, perubahan lay-out toko, merchandise grouping dan metode display serta strategi marketing-nya.

2. Perubahan struktur organisasi, di mana diadakan perubahan struktur organisasi, rancang-ulang fungsi departemen, pembentukan departmen baru (marketing) di bawah seorang direksi, dan rancang-ulang jabatan yang disesuaikan dengan fungsi jabatan yang baru.

3. Pergantian direksi dan manajer, dimana kehadiran direksi dan manajer baru dari eksternal telah melahirkan konsep dan strategi bisnis baru, ide-ide dan inovasi yang baru serta standar kerja yang tinggi.

4. Perubahan kebijakan dan peraturan, dimana dicanangkannya tuntutan kinerja tinggi melalui performance evaluation berdasarkan target kerja dan
achievement-nya. 
Beliau menggunakan gaya kepemimpinan yang berorientasi pada prestasi yang diikuti dengan perubahan manajemen yang terjadi. Perubahan manajemen yang terjadi ini memiliki pengaruh terhadap budaya organisasi Alfa yang telah lama mengakar sebelumnya dan diduga dapat mempengaruhi kinerja manajernya.

Permasalahan dapat diidentifikasikan sebagai berikut:

1. Perubahan struktur organisasi yang menyebabkan rancang-ulang jabatan dan perubahan pejabat pada level manajer, telah mengakibatkan demotivasi bagi sebagian manajer.

2. Bergabungnya direksi dan manajer baru yang membawa budaya organisasi baru, menyebabkan hubungan kerja dan suasana kerja yang kurang kondusif di antara manajer.

3. Ide-ide, konsep dan strategi bisnis baru yang dimunculkan oleh direksi dan manajer baru, belum dapat sepenuhnya diterima oleh manajer lama.

4. Kebijakan perusahaan yang baru belum dapat diterima sepenuhnya oleh para manajer, karena hal itu mengurangi kenyamanan dan keuntungan finansial yang telah diperoleh sebelumnya.

\section{PERUBAHAN MANAJEMEN}

Perubahan terencana merupakan istilah yang pertama kali diperkenalkan oleh Kurt Lewin (1951) untuk membedakan perubahan yang sengaja digerakkan dan direncanakan organisasi, dari jenis perubahan lain yang berlangsung tanpa disengaja, karena sekadar impuls atau perubahan yang dipaksakan pada organisasi.

Menurut Greenberg and Baron (1997), perubahan organisasi (manajemen) merupakan transformasi secara terencana atau tidak terencana di dalam struktur, teknologi, dan manusianya. Daya penggerak untuk proses-proses perubahan dalam suatu organisasi dapat datang dari dalam (internal) dan dari luar (eksternal). Menurut Grundy (1993) seperti dikutip oleh Sulaksana (2004), ada tiga jenis perubahan organisasi sesuai dengan sifatnya, yaitu :

1) Smooth incremental change, dimana perubahan terjadi secara lambat, sistematis, dan dapat diprediksikan serta mencakup rentetan perubahan yang berlangsung pada kecepatan konstan.

2) Bumpy incremental change, dimana perubahan ini dicirikan sebagai periode relatif tenang yang sekali-sekali disela percepatan gerak perubahan yang dipicu oleh perubahan lingkungan organisasi, dan juga bisa bersumber dari perubahan internal seperti tuntutan peningkatan efisiensi dan perbaikan metode kerja.

3) Discontinous change, dimana perubahan ditandai oleh pergeseran-pergeseran cepat atas strategi, struktur, atau budaya, atau ketiganya sekaligus.

Tushman, Newman dan Romanelli (1998) seperti dikutip oleh Sulaksana (2004) men-definisi-kan discontinuous change tersebut di atas sebagai framebreaking change, yaitu perubahan sIstem yang bersifat revolusioner dan cepat, yang biasanya mencakup hal-hal, sebagai berikut: 
1) Reformasi misi dan nilai-nilai inti (core values) - perumusan ulang misi perusahaan.

2) Pergeseran kekuasaan dan status merefleksikan pergeseran basis persaingan dan alokasi sumber daya.

3) Reorganisasi strategi baru memerlukan modifikasi struktur, sistem dan prosedur, arus kerja, jaringan komunikasi, pola pengambilan keputusan.

4) Eksekutif baru, biasanya dari luar perusahaan. adalah :

Tujuan implementasi frame-breaking change secara cepat dan simultan,

1) Sinergi - semua bagian perusahaan perlu bergerak serentak.

2) Kantong-kantong resistensi - punya peluang berkembang dan memperkuat diri apabila frame-breaking change berjalan lambat.

3) Kebutuhan pada perubahan yang dibatasi - apabila hambatan-hambatan diperlonggar, maka perubahan menjadi mode.

4) Resiko dan ketidakpastian - semakin lama waktu implementasi, makin lama pula berlangsung ketidakpastian dan ketidakstabilan.

\section{MENGELOLA PERUBAHAN MANAJEMEN SECARA EFEKTIF}

Menurut Sulaksana (2004), untuk mengelola perubahan manajemen secara efektif diperlukan kemampuan untuk menciptakan sintesa antara pekerja, sumber daya, gagasan, peluang, dan tuntutan. Manajemen puncak harus memiliki tiga keterampilan kunci, yaitu :

1) Mengelola transisi secara efektif, yaitu dengan membuat strategi perubahan dan belajar dari perubahan,

2) Menangani budaya organisasi dan perubahan-perubahan yang terjadi terhadap budaya peran (role culture) dan budaya tugas (task culture)

3) Politik perubahan organisasi, dengan fokus pada koalisi dominan yang memiliki pengaruh kuat atas keputusan, penggunaan sumber-daya dan perubahan-perubahan lainnya.

Manajer memiliki 'basis pengetahuan' dan juga 'keahlian' untuk mengelola perubahan manajemen secara efektif. Namun, tingginya tingkat kegagalan program perubahan manajemen meng-indikasi-kan bahwa sebenarnya kebanyakan manajer tak memenuhi harapan tersebut.

Penyebab kegagalan perubahan manajemen bisa beragam, namun kebanyakan bersumber dari dalam organisasi, antara lain :

1) Semua orang memandang perubahan manajemen sebagai tujuan daripada sebagai sebuah proses yang memerlukan perencanaan, persiapan, manajemen proyek dan perhatian yang konsisten.

2) Visi tentang tujuan jangka pendek maupun jangka panjang tidak jelas.

3) Peninggalan program perubahan manajemen sebelumnya yang gagal karena penanganan buruk, menciptakan budaya skeptis dan cenderung menghindari resiko.

4) Gagal memberikan dukungan, pelatihan dan keterampilan yang diperlukan yang memungkinkan karyawan mampu ber-adaptasi dan menyesuaikan diri atas perubahan manajemen. 
5) Kurangnya komunikasi menyangkut perubahan termasuk, misalnya, memberi informasi kepada karyawan terlalu bertahap, yang beresiko tumbuhkembangnya gosip-gosip.

6) Terlalu memfokuskan upaya perubahan secara sempit pada satu aspek organisasi dan mengabaikan 'keterkaitannya' pada kehidupan organisasi.

\section{BUDAYA ORGANISASI}

Ada beberapa pandangan dari pakar tentang pengertian budaya organisasi dan dimensi-dimensi yang terkandung di dalamnya. Menurut Robbins (2001), budaya organisasi menyatakan suatu persepsi bersama yang dianut oleh anggota-anggota organisasi itu. Budaya dominan mengungkapkan nilai-nilai inti yang dianut bersama oleh mayoritas anggota organisasi itu. Sub budaya mencerminkan masalah, situasi, atau pengalaman bersama yang dihadapi oleh anggotanya.

Menurut Kotter \& Heskett seperti dikutip oleh Brown (1998), budaya organisasi adalah nilai dan praktik yang dimiliki bersama oleh seluruh kelompok dalam suatu organisasi, sekurang-kurangnya manajemen senior. Budaya organisasi dapat dilihat dalam 2 (dua) tingkat, yaitu :

1) yang terlihat pada permukaan, umumnya menyangkut perilaku dan sikapsikap dalam hubungan dengan benda-benda fisik

2) yang lebih dalam, umumnya menyangkut nilai-nilai yang dianut bersama.

Sedangkan Schein seperti dikutip oleh Brown (1998) membagi budaya organisasi ke dalam 3 (tiga) tingkatan, yaitu :

1) artifacts (artefak), yaitu manifestasi yang paling tampak dan paling dangkal, dan pada umumnya mengacu pada lingkungan fisik total dan tersusun secara sosial dari suatu organisasi.

2) espoused values (nilai-nilai, keyakinan dan sikap), yaitu nilai-nilai yang berkaitan dengan moral dan kode etik dan menentukan apa-apa yang orang pikirkan tentang yang dapat atau harus dilakukan, dan keyakinan dan sikap yang berkaitan dengan apa yang salah dan apa yang benar

3) basic underlying assumptions (asumsi dasar), yaitu suatu solusi yang dianggap benar atas suatu masalah yang diidentifikasi.

Brown (1998) dalam bukunya 'Organisational Culture', memberikan beberapa definisi tentang budaya organisasi, antara lain :

1) " The culture of an organization refers to the unique configuration of norms, values, beliefs, ways of behaving and so on that characterize the manner in which groups and individual combine to get things done." (Eldridge and Crombie, 1974: 89)

2) "Culture is a pattern of beliefs and expectations shared by the organization's member. The beliefs and expectations produce norms that powerfully shape the behavior of individuals and groups in the organization." (Schwartz and Davis, 1981: 33)

3) "Corporate culture may be described as a general constellation of beliefs, mores, customs, value systems, behavioral norms, and ways of doing business that are unique to each corporation, that set a pattern for corporate activities and actions, and that describe the implicit and 
emergent patterns of behavior and emotions characterizing life in the organization." (Tunstall, 1983: 15)

4) "Corporate culture is the implicit, invisible, intrinsic and informal consciousnesses of the organization which guides the behavior of the individuals and which shapes itself out of their behavior." (Scholz, 1987: 80)

5) "Culture refers to the underlying values, beliefs, and priciples that serve as a foundation for an organization's management system as well as the set of management practices and behaviors that both exemplify and reinforce those basic priciples." (Denison, 1990: 2)

Dengan mendasarkan berbagai definisi tentang budaya organisasi di atas, maka penulis menyimpulkan bahwa budaya organisasi adalah nilai-nilai dan keyakinan bersama yang diambil dari kebiasaan dan kemudian ber-interaksi dan menjadi norma-norma dan pedoman cara berpikir dan bertindak dalam upaya mencapai tujuan organisasi.

\section{HUBUNGAN ANTARA BUDAYA ORGANISASI DENGAN KINERJA ORGANISASI}

Ada beberapa hal yang harus dicermati dalam mengelola budaya organisasi dalam rangka meningkatkan kinerja karyawan, antara lain :

a) Pengaruh manajemen puncak terhadap budaya organisasi baru

b) Kepercayaan individu terhadap budaya organisasi baru

c) Dukungan dan komitmen individu terhadap budaya organisasi baru

d) Koordinasi antar bagian/departemen/unit kerja

e) Pengaruh dan dukungan atasan terhadap budaya organisasi baru

f) Pengendalian individu terhadap perilaku karyawan/ bawahannya

\section{KINERJA MANAJER}

Seorang manajer yang ditempatkan dan diberikan tugas (pekerjaan) dan tanggung-jawab atau kepercayaan untuk memimpin suatu organisasi atau unit kerja, yang bersangkutan diharapkan mampu mewujudkan kinerja yang baik dan memberikan kontribusi yang maksimal terhadap pencapaian tujuan organisasi.

Menurut Black (1975), manajer tidaklah sama dengan karyawan biasa. Ia harus memutuskan cara yang terbaik untuk mengerjakan tugasnya, bagaimana menguraikan tugas-tugasnya itu menjadi penugasan-penugasan kerja yang harus didelegasikan kepada para karyawan yang telah dipilih dan dilatihnya.

Seorang manajer bertanggung-jawab atas perencanaan (planning), pengarahan (directing), pengkoordinasian (coordinating), dan pengendalian (controlling) kegiatan-kegiatan daripada kelompok karyawan dan memberikan bimbingan bagi usaha mereka bersama untuk mencapai tujuan yang diinginkan bersama.

Kinerja adalah hasil dari fungsi suatu pekerjaan atau kegiatan tertentu selama suatu periode waktu tertentu. (Bernardin and Russel, 1993). 
Berdasarkan pengertian tersebut, maka ada tiga aspek yang perlu dipahami, yaitu :

a. Kejelasan tugas atau pekerjaan yang menjadi tanggung-jawabnya.

b. Kejelasan hasil yang diharapkan dari suatu pekerjaan atau fungsi.

c. Waktu yang diperlukan menyelesaikan suatu pekerjaan agar hasil yang diharapkan dapat terwujud.

Sianipar (1999) memberikan pengertian bahwa kinerja adalah hasil kerja atau kemampuan kerja yang diperlihatkan seseorang atas pekerjaannya pada waktu tertentu.

Dengan mendasarkan berbagai definisi mengenai manajer dan kinerja di atas, maka penulis menyimpulkan bahwa kinerja manajer adalah hasil kerja yang dicapai oleh manajer dalam suatu perusahaan selama periode tertentu sesuai dengan fungsi, tugas, wewenang dan tanggung-jawabnya dalam rangka mencapai target kerja dan tujuan perusahaan.

\section{METODOLOGI PENELITIAN}

Penulis menggunakan metoda penelitian survey untuk mengetahui hubungan dan pengaruh antar variabel (asosiatif) guna memperoleh penjelasan dan peramalan serta pengendalian suatu gejala yang berkaitan dengan masalah.

Fokus variabel terdiri dari satu variabel independen, satu variabel intervening dan satu variabel dependen. Dalam penelitian ini, variabel independen $\left(\mathrm{X}_{1}\right)$ adalah Perubahan Manajemen, variabel intervening $\left(\mathrm{X}_{2}\right)$ adalah Budaya Organisasi, dan variabel dependen (Y) adalah Kinerja Manajer.

Pengaruh antar variabel tersebut terdiri dari satu variabel independen, satu variabel intervening dan satu variabel dependen berupa pengaruh/ hubungan kausal. Hubungan variabel dimaksud digambarkan sebagai berikut:

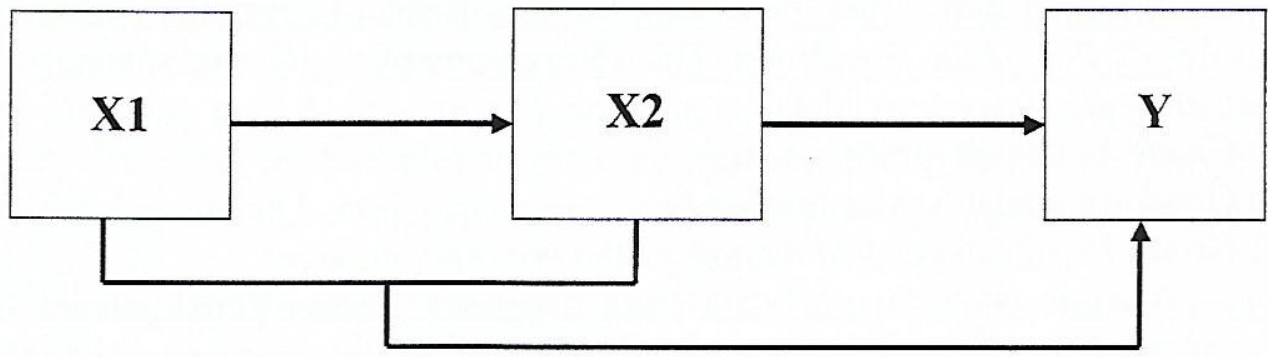

$$
\begin{array}{lll}
\mathrm{X} 1 & = & \text { Perubahan Manajemen (variabel independen) } \\
\mathrm{X} 2 & = & \text { Budaya Organisasi (variabel intervening) } \\
\mathrm{Y} & = & \text { Kinerja Manajer (variabel dependen) }
\end{array}
$$

Hipotesis penelitian sesuai dengan permasalahan yang telah ditetapkan dan harus diuji kebenarannya, yaitu :

1. Diduga terdapat pengaruh yang positif dan signifikan antara perubahan manajemen dengan budaya organisasi. 
2. Diduga terdapat pengaruh yang positif dan signifikan antara budaya organisasi dengan kinerja manajer.

3. Diduga terdapat pengaruh yang positif dan signifikan antara perubahan manajemen dan budaya organisasi secara bersama-sama terhadap kinerja manajer.

Ketiga variabel penelitian, yaitu Perubahan Manajemen, Budaya Organisasi dan Kinerja Manajer selanjutnya akan dioperasionalisasikan dan diukur skalanya. Skala pengukuran yang digunakan adalah semantic differential.

Kolom paling kiri untuk nilai peringkat yang paling rendah dan paling kanan untuk yang paling tinggi. Sedangkan kolom yang lain untuk nilai di antara yang paling rendah dan paling tinggi.

Nilai skor untuk skala ordinal dimaksud adalah :

- Nilai 1 - untuk tingkat yang paling rendah

- Nilai 2 - untuk tingkat yang kecil

- Nilai 3 - untuk tingkat cukup

- Nilai 4 - untuk tingkat besar

- Nilai 5 - untuk tingkat yang paling tinggi

Data yang digunakan dalam penelitian ini terdiri dari data kualitatif dan data kuantitatif. Data kualitatif berupa laporan, struktur organisasi, skema, gambar, kuesioner dan lain-lain. Data kuantitatif berupa data personal, data kualitatif yang diangkakan, dan lain-lain.

Data yang digunakan dalam penelitian ini menurut sumbernya terdiri dari data primer dan data sekunder. Data primer berupa data yang diperoleh dari hasil wawancara/interview/angket atas obyek penelitian. Data sekunder berupa data yang berasal dari literatur, data kepustakaan, data penelitian pihak lain, dan lainlain data sekunder.

Populasi dari obyek penelitian ini adalah seluruh manajer grade 13, 14, dan 15 di P.T. Alfa Retailindo Tbk. Pengelompokan jabatan manager sesuai dengan grading tersebut, adalah :

(1) Grade 13 adalah junior manager,

(2) Grade 14 adalah senior manager,

(3) Grade 15 adalah general manager atau regional manager

Metode pengumpulan data yang digunakan dalam penelitian ini berupa wawancara dan angket/kuesioner. Wawancara dilakukan oleh peneliti pada studi pendahuluan bertujuan untuk mengetahui permasalahan yang akan diteliti serta untuk mengetahui hal-hal dari responden secara lebih mendalam. Wawancara tersebut dilakukan secara tatap-muka dengan wawancara tidak terstruktur. Setelah mengetahui permasalahan dari wawancara dimaksud, maka pengumpulan data penelitian dilakukan dengan angket/kuesioner yang selanjutnya dilakukan analisa angket melalui Skala Semantic Differential dengan skala pengukuran ordinal setelah terlebih dahulu diuji validitas dan reliabilitasnya dengan menggunakan uji Cronbach's Alpha.

Untuk menguji hipotesis asosiatif/hubungan, analisis statistika yang digunakan adalah Koefisien Rank-Spearman. 
Untuk menghitung nilai korelasi antara data pada masing-masing pernyataan dengan skor total memakai teknik korelasi product moment dengan rumusan hipotesis, sebagai berikut :

Hipotesis yang diuji adalah :

$$
H_{0}: \rho_{j t}=0 \quad H_{1}: \rho_{j t} \neq 0
$$

Dengan menggunakan taraf uji $\alpha$ dan derajat bebas $(\mathrm{db})=n-2$, akan diperoleh nilai $\mathrm{t}_{(\alpha / 2 ; d b)}$ dari tabel sebaran $t$-student. Kriteria ujinya adalah tolak Ho jika $\left|t_{\text {hit }}\right|>t_{(\alpha / 2 ; d b)}$ atau disimpulkan terdapat korelasi yang signifikan antara skor variabel ke-j dengan total skor variabel.

Sebaliknya, terima Ho jika $\left|t_{\text {hit }}\right|<\mathrm{t}_{(\alpha / 2 ; d b)}$ atau disimpulkan tidak terdapat korelasi yang signifikan antara skor variabel ke-j dengan total skor variabel (dihilangkan atau redaksi diperbaiki).

Untuk mengetahui keterandalan kuesioner dilakukan Uji Reliabilitas Alpha - Cronbach. Metode ini digunakan untuk menghitung reliabilitas instrumen yang skornya merupakan rentangan dari beberapa nilai.

Metode analisis sesuai dengan hipotesis yang telah ditetapkan adalah untuk mengetahui besar pengaruh dari variabel independen (Perubahan Manajemen) terhadap variabel intervening (Budaya Organisasi), dan pengaruh dari variabel intervening (Budaya Organisasi) terhadap variabel dependen-nya (Kinerja Manajer), yaitu dengan menggunakan Model Analisis Korelasi RankSpearman.

Nilai korelasi berkisar dari $-1 \mathrm{ke}+1$ di mana nilai -1 memiliki korelasi kuat tetapi berbalik dari yang +1 . Sedangkan nilai 0 berarti tidak ada korelasi.

Untuk menentukan suatu keadaan tertentu yang mungkin disebabkan oleh faktor-faktor tertentu, maka untuk menjawab masalah-masalah tersebut, perlu diteliti apakah memang ada hubungan yang signifikan antara kedua sebab-akibat tersebut. Dalam persamaan matematis, hubungan ini dinyatakan dalam bentuk regresi linier. Cara yang sederhana adalah dengan membuat grafik dalam suatu scatter diagram, atau dengan suatu operasi matematis. Dengan memakai scatter diagram, data yang telah di-plot secara sederhana dapat dilihat apakah kumpulan data dapat dinyatakan berada pada suatu garis lurus (linier) atau tidak lurus (nonlinier).

Pendugaan persamaan regresi linier sederhana dengan menggunakan metode Ordinary Least Squares (OLS).

Untuk mengetahui besar pengaruh secara bersama-sama kedua variabel, yaitu variabel independen (perubahan manajemen) dan variabel intervening (budaya organisasi) terhadap variabel dependen (kinerja manajer), maka dilaksanakan dengan menggunakan model analisis regresi linier berganda.

Secara umum, data hasil pengamatan $\mathrm{Y}$ dipengaruhi oleh variabel-variabel independen $\mathrm{X}_{1}$ dan variabel intervening $\mathrm{X}_{2}$.

Sedangkan untuk pengolahan datanya dengan menggunakan program komputer SPSS (Statistical Program for Social Science) for Windows. 


\section{HASIL PENELITIAN}

Dari hasil perhitungan diperoleh koefisien reliabilitas yang cukup tinggi, yaitu sebesar $\mathbf{0 , 8 5 1}$.

Dari hasil kedua uji di atas, maka disimpulkan bahwa kuesioner valid dan reliable sehingga dapat digunakan sebagai alat untuk mengumpulkan data. bawah ini :

Besarnya korelasi Rank-Spearman antar variabel disajikan pada tabel di

\begin{tabular}{|c|c|c|c|c|c|}
\hline Analisis & Variabel & Correlations & $\begin{array}{l}\text { Perubahan } \\
\text { Manajemen }\end{array}$ & $\begin{array}{l}\text { Budaya } \\
\text { Organisasi }\end{array}$ & $\begin{array}{l}\text { Kinerja } \\
\text { Manajer }\end{array}$ \\
\hline \multirow{9}{*}{ 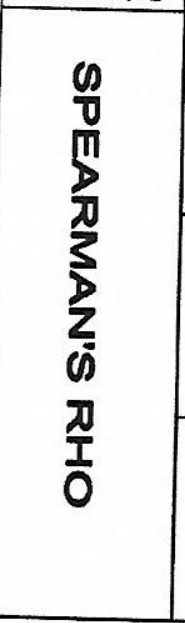 } & \multirow{3}{*}{$\begin{array}{l}\text { Perubahan } \\
\text { Manajemen }\end{array}$} & $\begin{array}{l}\text { Correlation } \\
\text { Coefficient }\end{array}$ & 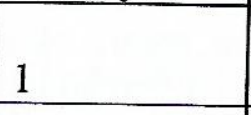 & $.783^{* *}$ & $.388 * *$ \\
\hline & & Sig. (2-tailed) & & 0 & 0 \\
\hline & & $\mathrm{N}$ & 96 & 96 & 96 \\
\hline & \multirow{3}{*}{$\begin{array}{l}\text { Budaya } \\
\text { Organisasi }\end{array}$} & $\begin{array}{l}\text { Correlation } \\
\text { Coefficient }\end{array}$ & $.783^{* *}$ & 1 & $.368 * *$ \\
\hline & & Sig. (2-tailed) & 0 & & 0 \\
\hline & & $\mathrm{N}$ & 96 & 96 & 96 \\
\hline & \multirow{3}{*}{$\begin{array}{l}\text { Kinerja } \\
\text { Manajer }\end{array}$} & $\begin{array}{l}\text { Correlation } \\
\text { Coefficient }\end{array}$ & $.388 * *$ & $.368^{* *}$ & 1 \\
\hline & & Sig. (2-tailed) & 0 & 0 & \\
\hline & & $\mathrm{N}$ & 96 & 96 & 96 \\
\hline
\end{tabular}

Budaya organisasi yang sudah terbentuk hanya berperan linier positif berkisar sebesar 13,5\% dengan kinerja manajer, sedangkan sisanya berasal dari variabel lain yang tidak dibahas dalam penelitian ini.

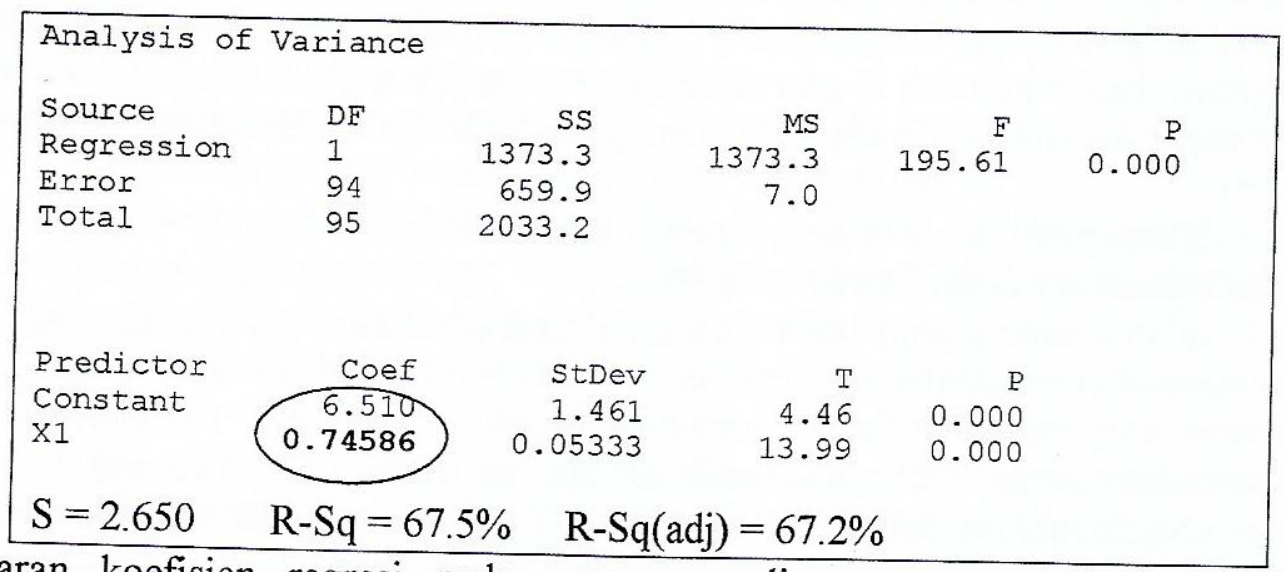

Besaran koefisien regresi pada persamaan di atas menggambarkan "laju" perubahan manajemen per-satu satuan "skor" memberikan kontribusi sebesar 0,746 terhadap budaya organisasi. Dari hasil analisis di atas, dapat disimpulkan bahwa Perubahan Manajemen yang dilakukan di Alfa memberikan kontribusi sebesar 74,6\% terhadap Budaya Organisasi yang dihasilkannya. 
Pengujian ragam homogen dilakukan dengan membuat grafik tebaran nilai data dugaan dengan nilai sisaan seperti pada gambar berikut.

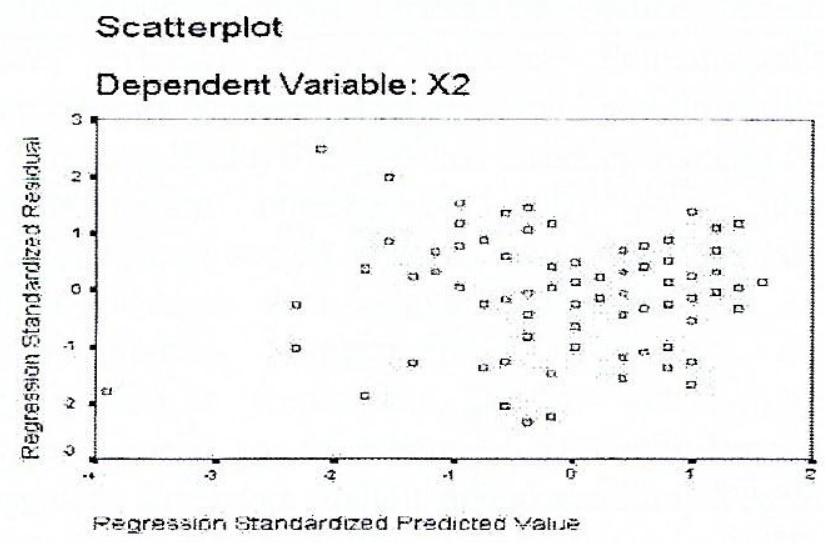

Grafik yang dihasilkan menunjukkan gambaran tidak terdapat gambaran "tren" atau pola tertentu. Sehingga disimpulkan ragam data homogen.

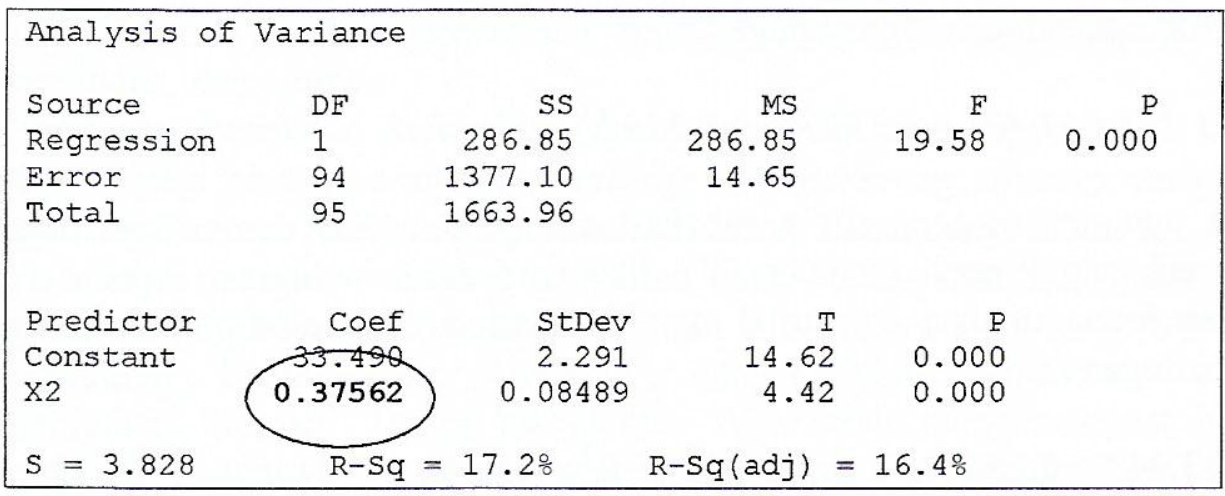

Besaran koefisien regresi pada persamaan menggambarkan "laju" Budaya Organisasi per satu satuan "skor" memberikan kontribusi sebesar 0,376 terhadap Kinerja Manajer. Dari hasil analisis di atas, dapat disimpulkan bahwa Budaya Organisasi yang tercipta akibat Perubahan Manajemen di Alfa memberikan kontribusi sebesar 37,6\% terhadap Kinerja Manajer - nya.

Pengujian ragam homogen dilakukan dengan membuat grafik tebaran nilai data dugaan dengan nilai sisaan seperti pada gambar berikut.

Scatterplot

Dependent Variable: $Y$

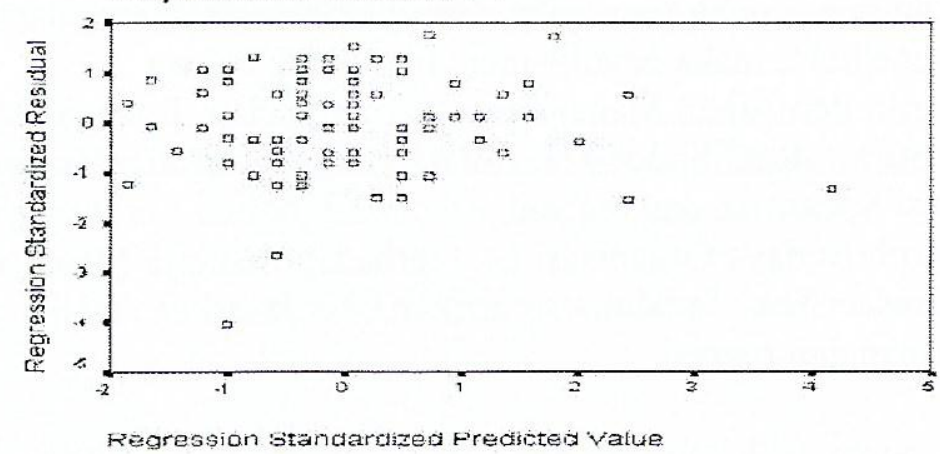


Grafik yang dihasilkan menunjukkan gambaran tidak terdapat gambaran "tren" atau pola tertentu. Sehingga disimpulkan ragam data homogen.

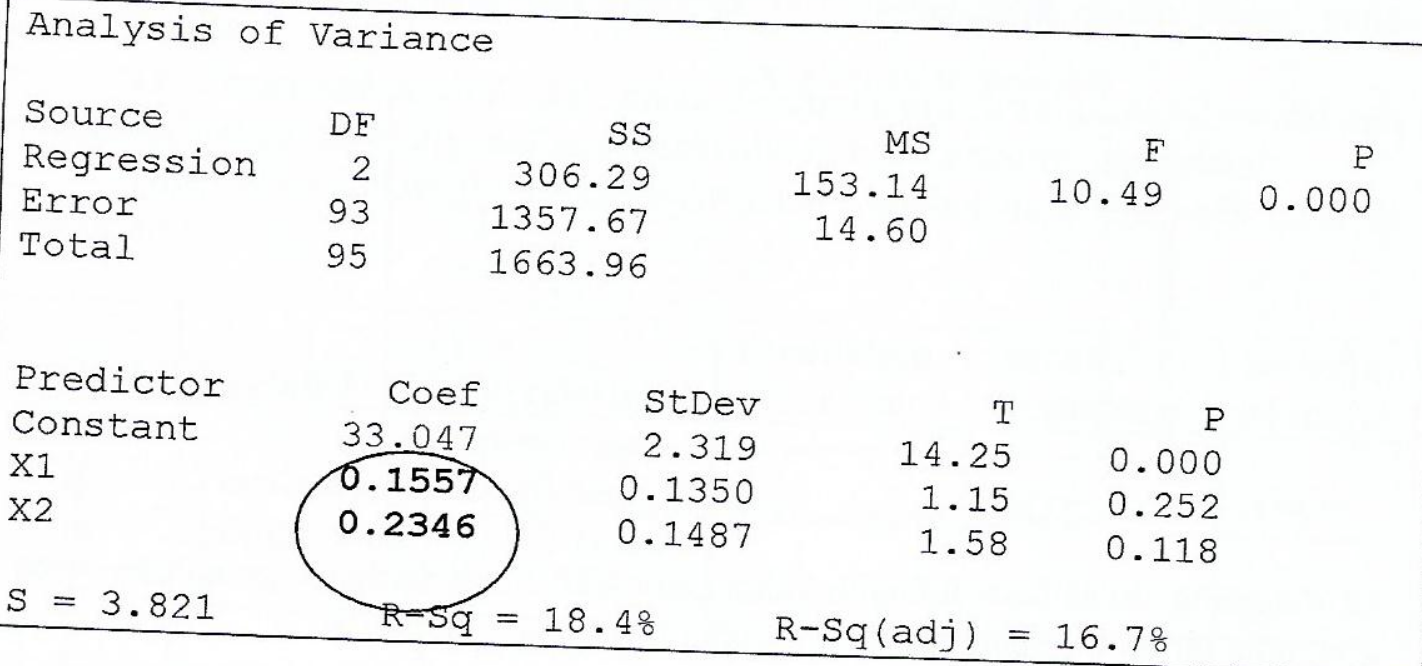

Diperoleh persamaan regresi dugaan :

$$
Y_{i}=33,407+0,156 X_{1 i}+0,235 X_{2 i} ; i=1,2, \ldots, 96
$$

Untuk mengetahui pengaruh perubahan manajemen $(X 1)$ dan budaya organisasi (X2) terhadap kinerja manajer (Y) dilakukan analisis regresi linier berganda. Dengan menggunakan data total skor dari setiap variabel diperoleh persamaan
regresi dugaan

$Y i=33,047+0,156 X_{1} i+0,235 X_{2} i \quad ; R^{2}=18,4 \%$

Dari hasil analisis ragam (Uji.-F) menunjukkan adanya pengaruh yang signifikan dari perubahan manajemen dan budaya organisasi secara simultan terhadap kinerja manajer pada taraf uji $1 \%(\mathrm{p}<0,01)$, dengan koefisien determinasi sebesar 18,4\%. Namun dari hasil Uji - t, dengan menggunakan taraf uji $20 \%$ (p $<0,20$ ) hanya variabel budaya organisasi yang menunjukkan adanya pengaruh signifikan terhadap kinerja manajer.

\section{KESIMPULAN}

Berdasarkan rangkuman penelitian dan pembahasan di atas dan untuk menjawab hipotesa penelitian, maka penulis menyimpulkan, bahwa :

1. Pengaruh Perubahan Manajemen $\left(X_{1}\right)$ terhadap Budaya Organisasi $\left(X_{2}\right)$ di PT Alfa Retailindo Tbk. adalah signifikan berdasarkan hasil analisis
korelasi Spearman dan regresi.

2. Pengaruh Budaya Organisasi $\left(X_{2}\right)$ terhadap Kinerja Manajer (Y) di PT Alfa Retailindo Tbk. adalah signifikan berdasarkan hasil analisis korelasi
Spearman dan regresi. 
3. Sesuai dengan hasil analisis regresi linier berganda - diperoleh persamaan regresi $\mathrm{Yi}=33,047+0,156 \mathrm{X}_{1} \mathrm{i}+0,235 \mathrm{X}_{2} \mathrm{i}$; menunjukkan bahwa Perubahan Manajemen dan Budaya Organisasi secara bersama-sama berpengaruh signifikan terhadap kinerja manajer. Pengaruh Perubahan Manajemen terhadap Kinerja Manajer $(15,6 \%)$ lebih kecil dibandingkan dengan pengaruh secara langsung Budaya Organisasi terhadap Kinerja Manajer (23,5\%).

4. Perubahan dalam budaya organisasi Alfa tidak serta-merta dapat diimplementasikan secara internal. Muncul hambatan internal yang bersifat psikologis terutama dari kalangan manager dan karyawan. Dikarenakan proses Perubahan Manajemen tidak segera ditindak-lanjuti dengan pengesahan Surat Keputusan Direksi untuk kebijakan yang bersifat fundamental, maka situasi seperti ini menimbulkan ketidakpastian bagi para manajer dan karyawan dalam melaksanakan fungsi, tugas dan tanggung jawabnya dalam mencapai tujuan perusahaan.

5. Kondisi tersebut telah menimbulkan persoalan manajemen dalam perusahaan, seperti: kurang lancarnya komunikasi dan koordinasi antar-departemen, munculnya mispersepsi atas tugas dan tanggung jawab manajer dan hubungan kerja antar-departemen, timbulnya keragu-raguan manajer untuk bertindak, dan lainnya.

6. Salah satu hasil dari Perubahan Manajemen Alfa adalah perubahan konsep dan strategi bisnis, yaitu merchandising dan marketing strategy yang fokus pada end-users. Akibat dari perubahan konsep dan strategi bisnis ini, adalah terjadinya penurunan tingkat penjualan yang cukup signifikan pada geraigerai Alfa, sebagai akibat langsung dari dihapusnya pricing policy untuk penjualan 'Lusinan dan Kartonan', dengan lebih difokuskannya pada penjualan 'Satuan' Tetapi manajemen Alfa telah mengantisipasi hal ini dengan mengubah penataan merchandise grouping disesuaikan dengan format supermarket yang berorientasi pada end-users dengan pricing policy baru yang dibagi menjadi tiga kategori, yaitu housewife-basket category, red category dan green category.

\section{DAFTAR RUJUKAN}

Bacal, Robert, 2002. Performance Management. Alih-bahasa: Surya Dharma dan Yanuar Irawan, Gramedia, Jakarta.

Bernardin, H. and Russel, EA. 1993. Human Resource Management, McGrawHill, Inc.

Brown, D.Andrew, 1998. Organisational Culture, Second Edition, Prentice Hall, Pearson Education Limited, Essex, England.

Bulletin Bisinfocus Data Pratama, 2003. Peta Bisnis Ritel Modern di Indonesia, Jakarta.

Coleman, Daniel, 2003. Leadership That Gets Results Kepemimpinan yang Mendatangkan Hasil. Alih-bahasa: Saptadi Bagastawa, Amara Books, Yogyakarta. 
Don Hellrigel, Susan E. Jackson and John W. Slocum, Jr., 2002. Management: A Competency-Based Approach, 9 Edition. Canada: South-Western Thompson Learning.

Freedman, Mike dan Tregoe, Benjamin, B., 2004. The Art and Discipline of Strategic Leadership. Alih-bahasa: Hikmat Kusumaningrat, Gramedia, Jakarta.

Greenberg, J. and Baron, RA. 1997. Behavior in Organization, Prentice Hall International Inc., New Jersey

Hasibuan, Malayu S.P., 2002. Manajemen Sumber Daya Manusia, Bumi Aksara, Jakarta.

Johnson , C.Marla, 2004. Handbook of Organizational Performance, Analisis Perilaku dan Manajemen. Alih-bahasa PT RajaGrafindo Persada, Jakarta.

Kotter, JP. 1996. Leading Change, Borton Harvard Business School Press.

Lako, Andreas, 2004. Kepemimpinan dan Kinerja Organisasi, Amara Books, Yogyakarta.

Marjono, 2004. Pengaruh Budaya Organisasi, Kepuasan Kerja dan Motivasi Kerja terhadap Kinerja Pejabat Eselon IV di Direktorat Jenderal Pemberdayaan Sumberdaya Kawasan Transmigrasi. Tesis Program Pasca Sarjana Universitas Indonusa Esa Unggul, Jakarta.

Muchtar, Supar. 2004. Pengaruh Motivasi Berprestasi dan Kesiapan Menerima Perubahan terhadap Kinerja Pegawai; Kasus Pusdiklat Pegawai Departemen Tenaga Kerja dan Transmigrasi. Tesis Program Pasca Sarjana Universitas Indonusa Esa Unggul, Jakarta.

PT Alfa Retailindo Tbk., 2004. Laporan Tahunan 2003 PT Alfa Retailindo Tbk.,
Tangerang Prawirosentono, Suyadi, 1999. Kebijakan Kinerja Karyawan. Penerbit BPFE,
Yogyakarta

Robbins, P. Stephen, 2001. Organizational Behavior. Alih-bahasa Tim Indeks Kelompok Gramedia, Jakarta. Sianipar, JP. 1999. Perencanaan Peningkatan Kinerja. Lembaga Administrasi
Negara, Jakarta

Sulaksana, Uyung, 2004. Perubahan Manajemen, Pustaka Pelajar, Jakarta. 
Tani, Andrew EB, 2003. Get Real, Berdayakan Manager-Leader dalam Diri Anda, Gramedia, Jakarta.

Tjondrorahardja, Daud Djiang, 2004. 100 Questions and Answers on Family Business, Graha Ilmu, Yogyakarta.

Umar, Husein, 2003. Metode Riset Bisnis, Gramedia, Jakarta.

Usmara, A., 2003. Handbook of Organizations, Kajian dan Teori Organisasi, Amara Books, Yogyakarta.

Williams, Pat, 1997. The Magic of Teamwork: proven principles for building a winning team, The New King James Version, Nashville, Tennessee

Winardi, J., 2001. Motivasi \& Pemotivasian dalam Manajemen, RajaGrafindo Persada, Jakarta. 